\title{
Pelatihan Tendangan Drill 10 Repetisi 5 Set Terhadap Peningkatan Kecepatan Tendangan Sabit Atlet Putri Pencak Silat
}

\author{
I Komang Adi Palgunadi ${ }^{1}$, Putu Citra Permana Dewi ${ }^{2}$, Kadek Dian Vanagosi ${ }^{3}$, Ni Luh \\ Putu Indrawathi ${ }^{4}$
}

1,2,3,4 Prodi Pendidikan Jasmani Kesehatan dan Rekreasi, Universitas PGRI Mahadewa Indonesia, Denpasar, Indonesia

\section{ARTICLE INF O}

Article history:

Received March 04, 2021

Revised March 09, 2021

Accepted July 07, 2021

Available online July 25, 2021

Kata Kunci:

Pelatihan, Kecepatan,

Tendangan Sabit, Pencak Silat

Keywords:

Training, Speed, Sabit-Kick,

Pencak Silat

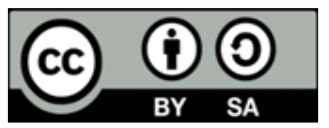

This is an open access article under the CC BY-SA license.

Copyright () 2021 by Author. Published by Universitas Pendidikan Ganesha.

\begin{abstract}
A B S T R A K
Lemahnya kemampuan atlet putri pencak silat saat melakukan serangan, tendangannya terutama tendangan sabit. mengakibatkan atelt kehilangan poin karena lawan mudah mengantisipasi serangan yang diberikan. Hal ini berdampak terhadap perolehan perstasi atlet. Penelitian ini bertujuan untuk mengetahui pengaruh pelatihan tendangan drill kanan kiri 10 repetisi 5 set terhadap peningkatan kecepatan tendangan sabit atlet putri pencak silat. Jenis penelitian yang digunakan yaitu penelitian eksperimen. Penelitian dilaksanakan selama 6 minggu. Sampel penelitian berjumlah 24 orang atlet putri, dibagi menjadi dua kelompok, masing-masing kelompok berjumlah 12 orang. Kelompok perlakuan diberikan pelatihan tendangan drill kanan kiri 10 repetisi 5 set. Pengumpulan data menggunakan instrument berupa tes. Data dianalisi dengan uji t-independen. Hasil analisis data menunjukkan rerata kecepatan tendangan sabit sesudah pelatihan pada kelompok perlakuan terjadi peningkatan 41,25\%, sedangkan kelompok kontrol terjadi peningkatan sebesar $19,28 \%$. Hasil t-test independent rerata tes akhir kecepatan tendangan sabit antara kelompok perlakuan dan kelompok kontrol sebesar -3,652 dengan nilai signifikansi 0,001 lebih kecil dari 0,05 $(p=0,001<0,05)$. Dapat disimpulkan bahwa pelatihan tendangan drill kanan kiri 10 repetisi 5 set memberikan pengaruh yang signifikan terhadap peningkatan kecepatan tendangan sabit atlet putri pencak silat BN Kintara.
\end{abstract}

\begin{abstract}
A B S T R A K
The weak ability of female pencak silat athletes when carrying out attacks, especially kicks with sickles. causes the athlete to lose points because the opponent easily anticipates the attack given. This has an impact on the achievement of athletes. This study aims to determine the effect of drill kick training on the right and left for 10 repetitions of 5 sets on increasing the speed of the sickle kick of female pencak silat athletes. The type of research used is experimental research. The study was carried out for 6 weeks. The research sample consisted of 24 female athletes, divided into two groups, each group consisted of 12 people. The treatment group was given training on drill kicks right and left for 10 repetitions of 5 sets. Collecting data using an instrument in the form of a test. Data were analyzed by independent t-test. The results of data analysis showed that the average speed of the sickle kick after training in the treatment group increased by $41.25 \%$, while the control group increased by $19.28 \%$. The results of the independent t-test average of the sickle kick speed final test between the treatment group and the control group was -3.652 with a significance value of 0.001 less than 0.05 $(p=0.001<0.05)$. It can be concluded that the drill kick training on the right and left for 10 repetitions of 5 sets has a significant effect on increasing the speed of the sickle kick of the female pencak silat athlete BN Kintara.
\end{abstract}




\section{PENDAHULUAN}

Pencak silat merupakan salah satu bentuk kebudayaan warisan nenek moyang bangsa Indonesia. Pencak silat adalah sistem pembelaan diri yang memiliki gerakan-gerakan yang unit melibatkan semua komponen tubuh manusia (Sumantri, Sulaiman, \& Nasuka, 2016). Wongsonegoro ketua IPSI ke-1 mengatakan bahwa pencak silat adalah gerakan beladiri yang dikemas dalam bentuk tari, dan berirama yang tetap menjunjung kesopanan, dan bisa dipertunjukan kepada masyarakat umum (Hartoyo, 2015; Mulyana, 2014). Pencak silat sangat diyakini oleh para pendekarnya dan pakar pencak silat bahwa masyarakat melayu saat ini menciptakan dan mempergunakan ilmu bela diri ini sejak di masa prasejarah (Lubis Johansyah \& Wardoyo Hendro, 2016). Kini pencak silat sudah menjadi olahraga beladiri yang telah dipertandingkan dalam berbagai events olahraga, baik tingkat daerah, nasional maupun internasional (Ihsan, Sepriadi, \& Suwirman, 2018).

Pencak silat sebagai beladiri mempunyai ciri-ciri umum menggunakan seluruh bagian tubuh dan anggota badan sebagai alat pembelaan diri, dapat dilakukan dengan tangan kosong atau menggunkan senjata (Muhtar, 2020). Gerak Dasar pencak silat adalah suatu gerak terencana, terarah, terkendali, dan tekoodinasi, yang mempunyai empat aspek sebagai suatu kesatuan yaitu aspek mental spiritual, bela diri, olahraga an seni (Kholis, 2016; Spyanawati \& Mudariani, 2015). Dalam pertandingan beladiri pencak silat terdapat beberapa perbedaan dengan cabang beladiri lainnya. Seorang pesilat saat bertanding dituntut menampilkan sikap pasang, pola langkah dengan keseimbangan, beberapa teknik serangan dan elakan yang kemudian kembali ke sikap pasang salah satu teknik dalam beladiri pencak silat yaitu serangan dengan menggunakan kaki atau sering disebut tendangan. Tendangan merupakan serangan yang menghasilkan poin lebih banyak jika dibandingkan dengan pukulan, apabila berhasil mengenai lawan dengan bersih. Terdapat beberapa jenis tendangan dalam pencak silat, diantaranya adalah tendangan lurus, tendangan sabit dan tendangan samping dan tendangan belakang. (Marlianto, Yarman, Sutisyana, \& Defliyanto, 2018; Marlianto \& Yarmani, 2018; Nugraha, 2014; Yarmani \& Japriansyah, 2017).

Tendangan sabit merupakan tendangan yang lintasannya setengah lingkaran ke dalam, dengan sasaran seluruh bagian tubuh, dengan punggung telapak kaki atau jari telapak kaki (Sudiana \& Sepyanawati, 2017). Tendangan sabit merupakan salah satu teknik yang dapat dilakukan saat pertandingan dan termasuk bentuk serangan dalam pencak silat. Hamdani (2014) menjelaskan, serangan adalah usaha pembelaan diri dengan menggunakan lengan (tangan) atau tungkai (kaki), untuk mengenai sasaran tertentu pada tubuh lawan. Tendangan yang dilakukan saat pertandingan selain tepat sasaran harus juga cepat agar lawan tidak mudah mengantisipasi serangan. Tendangan yang baik adalah tendangan yang sulit untuk dibaca, atau di antisipasi, maupun ditangkap oleh lawan (Yarmani \& Japriansyah, 2017). Tendangan sabit merupakan bentuk serangan yang sering kali menghasilkan poin atau angka yang lebih jelas dan telak dibandingkan serangan lainnya. (Marlianto et al., 2018). Yang harus diperhatikan dalam melakukan tendangan untuk memperoleh poin adalah kecepatan Kecepatan merupakan kemampuan seseorang dalam melakukan gerakan-gerakan dalam satuan waktu tertentu untuk dapat menyelesaikan suatu jarak tertentu dalam waktu yang singkat (Syafruddin, 2011). Komponen kecepatan merupakan salah satu kondisi fisik yang memberikan kontribusi positif terhadap kemampuan tendangan sabit. Kecepatan merupakan salah satu elemen kondisi fisik yang sangat penting dalam banyak cabang olahraga. Namun berdasarkan hasil wawancara peneliti dengan Ketua BN Kintara beliau mengatakan bahwa prestasi atlet belakangan ini menunjukkan penurunan. Hal ini dapat dilihat dari kurang berhasilnya para atlet perguruan memperoleh medali pada kejuaraan tingkat daerah, regional, maupun nasional. Dalam beberapa pertandingan, menunjukkan masih banyak atlet putri pencak silat BN KINTARA saat melakukan serangan, tendangannya terlihat lemah terutama tendangan sabit. Lemahnya tendangan ini mengakibatkan atlet kehilangan poin karena lawan mudah mengantisipasi serangan yang diberikan. Hal ini disebabkan karena kecepatan tendangan atlet kurang optimal. Kondisi fisik sangat berpengaruh terhadap prestasi seorang atlet (Sinulingga, Simatupang, \& Mentari, 2020; Supriyoko \& Mahardika, 2018). Penelitian oleh (Nurul Ihsan, 2018) yang menyatakan permasalahan yang sering terjadi dalam pertandingan pencak silat adalah banyak atlet yang kurang mampu mengantisipasi gerakan dan serangan dari lawan. Selain itu, pesilat juga tidak mampu melancarkan serangan balikan secara cepat. Salah satu faktor yang mungkin menjadi penyebab dalam hal ini adalah konsentrasi atlet yang sering tidak fokus. . Selain itu faktor yang menyebabkan rendahnya prestasi siswa adalah pembibitan atlet yang kurang terprogram secara baik, latihan hanya bersifat insidental dan tidak berkesinambungan sehingga kualitasyang didapattidak maksimal (Sudirman, 2015). Kelemahan atlet pencak silat dapat dilihat dari aspek psikologis yang menunjukkan atlet pencak mempunyai perasaan tidak percaya diri, kurang motivasi, tertutup, pendiam, cepat marah dan mudah tersinggung (Rosalina, 2017).

Dengan melihat kondisi di atas maka diperlukan suatu teknik latihan khusus dalam melatih kecepatan tendangan. Pelaksanaan teknik dasar yang baik dan benar sangat diperlukan dalam pertandingan pencak silat, cara yang harus dilakukan adalah dengan menjalani latihan dengan program 
latihan yang direncanakan (Pratiwi et al., 2013). Selama ini pelatihan beladiri Pencak Silat memfokuskan melatih teknik ketepatan, kecepatan, kelincahan, dan kekuatan, padahal kenyataannya Kecepatan tendangan sangat di perlukan dalam pertandingan untuk mencegah tendangan balasan dari lawan, oleh karena itu pelatihan ini sangat di perlukan dalam meningkatkan prestasi atlet putri BN Kintara, untuk meningkatkan Kecepatan tendangan sabit. Latihan adalah penerapan dari suatu perencanaan untuk meningkatkan kemampuan berolahraga yang berisikan materi teori dan praktek, metode dan aturan pelaksanaan sesuai dengan tujuan dan sasaran yang akan dicapai (Sukadiyanto dan Dangsina Muluk, 2011). Dalam latihan terdapat poin penting yaitu sistematis, dilakukan berulang-ulang, jangka waktu lama, peningkatan beban secara bertahap dan terus-menerus, kemampuan masing-masing individu (Palar, Wongkar, \& Ticoalu, 2015). Latihan adalah aktifitas untuk meningkatkan kualitas fungsi sistem organ tubuh manusia sehingga mempermudah atlet dalam penyempurnaan geraknya (Saputra, Syafria, \& Sofino, 2018). Proses latihan harus dilakukan secara sistematis dan berkelanjutan. Latihan yang dilakukan dalam jangka waktu yang lama memerlukan energi yang relatif besar. sumber energi pada awal latihan diperoleh dari penggunaan glukosa yang sangat tinggi (Lesmana \& Broto, 2018). Proses latihan harus dilakukan dengan baik dan benar untuk menghindari terjadinya cedera fisik selama latihan. Tubuh tidak akan bisa mentolerir jika beban latihan yang diberikan terlalu berat sehingga dapat mengakibatkan kerusakan. Kerusakan yang bisa terjadi pada tubuh salah satunya cedera Delayed Onset Muscle Soreness (DOMS) (Lesmana, 2019). Latihan merupakan hal yang sangat penting guna memperbaiki atau meningkatkan semua komponen fisik untuk memperoleh hasil yang maksimal.

Hal ini sependapat dengan hasil penelitian yang dilakukan oleh (Dewi, 2014) terdapat kontribusi yang signifikan antara kelincahan dan kecepatan secara bersama-sama dengan kemampuan tendangan sabit pencak silat pada atlet usia 12-14 tahun. Untuk mengoptimalkan kecepatan tendangan maka perlu dilatih dengan motode latihan yang tepat dengan model latihan yang bervariasi. Seperti hasil penelitian yang dilakukan oleh (Bangun Novembrian Y.P \& Sugiyoto, 2017) menunjukkan kemampuan kecepatan tendangan sabit pada pesilat putra pembinaan prestasi pencak silat POK UNS tahun 2016/2017 meningkat secara signifikan setelah diberikan variasi latihan quickness. Penelitian lain juga menghasilkan pengaruh yang signifikan dengan menerapkan model latihan plyometrik terhadap kemampuan kecepatan tendangan pencak silat (Pratiwi, Purnomo, \& Mimi Haetami, 2018). Penelitian oleh (Sakti, Wibawa, \& Mulyajaya, 2017) yang menunjukkan hasil bahwa siswa yang melakukan latihan drill akan memperoleh kecepatan tendangan depan yang lebih baik dan memiliki skill yang bagus. Berdasarkan hasil penelitian yang relavan dapat disimpulkan bahwasannya dengan metode latihan driil mampu mempengaruhi kecepatan tendangan altet pencak silat. Selain itu metode latihan juga dapat melatih konsetrasi atlet. Adapun perbedaan penelitian ini dengan penelitain sebelumnya adalah pada gerakan latihan yang digunakan pelatihan yaitu tendangan drill 10 repetisi 5 set guna melatih kecepatan tendangan pada atlet pencak silat. Tujuan penelitian ini adalah untuk mengetahui pengaruh pelatihan tendangan drill kanan kiri 10 repetisi 5 set terhadap peningkatan kecepatan tendangan sabit atlet putri pencak silat.

\section{METODE}

Jenis penelitian ini adalah penelitian eksperimen. Adapun rancangan penelitian yang digunakan adalah rancangan experimental randomized pre-test and post-test groups design. Penelitian diawali dengan dilakukannya pretest untuk mengetahui keadaan awal, kemudian diberikan perlakuan atau pelatihan dan selanjutnya dilakukan posttest yang kemudian hasilnya diobservasi. Populasi penelitan adalah atlet pencak silat putri berjumlah 24 orang. Teknik penentuan sampel dengan total sampling karena jumlah populasi relatif kecil. Instrumen pengukuran yang digunakan yaitu tes kecepatan tendangan. Penelitian ini dilaksanakan di Ranting BN Kintara. Dilaksanakan selama 6 minggu, karena kemajuan yang telah dicapai akan tampak hasilnya (efek pelatihan) setelah 6 minggu. Hal ini diperkuat dengan pendapat yang menyatakan bahwa pelatihan yang telah dijalankan dengan tekun akan tampak hasilnya setelah $6-8$ minggu pelatihan dilakukan (Nala, 2015). Pada masa pelatihan waktu istiharat bagi seorang atlet tidak lebih dari 2 kali 24 jam karena jika lebih dari 2 kali 24 jam maka kondisi otot yang dilatih kembali seperti semula (Nala, 2015). Maka frekuensi pelatihan empat kali seminggu mulai pukul 16.00 wita sampai selesai. Data dikumpukan dengan menggunakan instrument tes kemampuan latihan drill. Data yang terkumpul kemudia diolah menggunakan perangkat lunak computer SPSS 16.0. Data yang diperoleh dianalisis dengan langkah-langkah sebagai berikut. Uji normalitas data dengan Shapiro Wilk Test, yang bertujuan untuk mengetahui normalitas data kecepatan masing-masing kelompok baik sebelum maupun sesudah pelatihan. Uji Homogenitas dengan Levene's Test bertujuan untuk mengetahui homogenitas data pengukuran kelincahan tendangan masing-masing kelompok. Uji t-paired test digunakan untuk menganalisis rerata perubahan hasil pengukuran kelincahan tendangan antara sebelum dan sesudah perlakuan pada masing- 
masing kelompok. Uji beda rerata pengukuran tendangan drill dengan $t$-independent test digunakan untuk menganalisis rerata perubahan antar kelompok perlakuan dan kelompok kontrol.

\section{HASIL DAN PEMBAHASAN}

\section{Uji Normalitas dan Homogenitas Data dan Kecepatan Tendangan}

Sebagai prasyarat untuk menentukan uji statistik yang akan digunakan maka dilakukan uji normalitas dan uji homogenitas data hasil pengukuran kecepatan tendangan sabit. Uji Normalitas dengan menggunakan uji Saphiro Wilk Test, sedangkan uji Homogenitas dengan menggunakan Levene Test yang hasilnya tertera pada Tabel 1. Berdasarkan hasil uji normalitas data (shapiro-wilk test) kecepatan tendangan sabit sebelum dan sesudah pelatihan pada kelompok kontrol dan kelompok perlakuan menunjukkan bahwa data pada kedua kelompok menunjukkan signifikansi hitung (p) lebih besar dari $0,05(\mathrm{p}>0,05)$, sehingga dinyatakan data tersebut berdistribusi normal. Demikian pula hasil uji homogenitas (levene test) menunjukkan bahwa data pada kedua kelompok berdasarkan hasil pengukuran memiliki varian yang homogen karena signifikansi hitung (p) lebih besar dari 0,05 $(p>0,05)$. Dengan demikian data dapat diuji dengan menggunakan uji parametrik untuk melihat adanya perbedaan rerata kedua kelompok.

Tabel 1. Hasil Uji Normalitas dan Homogenitas Kecepatan Sebelum dan Sesudah Pelatihan pada Kedua Kelompokga Menjadi Hal yang Penting

\begin{tabular}{cccc}
\hline $\begin{array}{c}\text { Pengukuran Kecepatan } \\
\text { Tendangan Sabit }\end{array}$ & $\begin{array}{c}\text { Kelompok Kontrol } \\
\text { Nilai p }\end{array}$ & $\begin{array}{c}\text { Kelompok Perlakuan } \\
\text { Nilai p }\end{array}$ & $\begin{array}{c}\text { Uji Homogenitas } \\
\text { (Levene-Test) }\end{array}$ \\
\hline Tes Awal & 0,369 & 0,018 & 0,856 \\
Tes Akhir & 0,726 & 0,228 & 0,079 \\
\hline
\end{tabular}

\section{Uji Beda Kecepatan Tendangan Sabit Sebelum dan Sesudah Perlakuan pada Masing-masing} Kelompok

Uji t-paired untuk membandingkan rerata kecepatan tendangan sabit sebelum dan sesudah pelatihan pada masing-masing kelompok dapat disampaikan seperti Tabel 2. Pada Tabel 2 tambak bahawa rerata kecepatan tendangan sabit sebelum dan sesudah pelatihan pada masing-masing kelomok mengalami peningkatan. Peningkatan yang terjadi pada msing-masing kelompok terbukti signifikan berdasarkan hasil nilai siginikansi hitung dari uji t-paired yaiu 0,00 lebih kecil dari 0,05. Untuk lebih jelasnya rerata perbedaan peningkatan kecepatan tendangan sabit pada kedua kelompok dapat dilihat pada Gambar 1 . Pada grafik tampak bahwa peningkaatan rerata kecepatan tendangan sabit pada kelompok perlakuan lebih tinggi dibandingkan pada kelompok kontrol.

\section{Uji Beda Rerata Peningkatan Kecepatan Tendangan Sabit Antar Kelompok}

Persentase perubahan hasil pengukuran kecepatan tendangan sabit setelah pelatihan selama 6 minggu pada kelompok perlakuan dan kelompok eksperimen, disajikan dalam Tabel 3. Peningkatan rerata kecepatan tendangan sabit pada kelompok perlakuan sebesar $41,25 \%$ sedangkan pada kelompok kontrol $29,28 \%$. Perbedaan peningkatan rerata kecepatan tendangan sabit antara kelompok perlakuan dan kelompok kontrol perlu di uji apakah perbedaan yang terjadi signifikan. Uji beda rerata peningkatan kecepatan tendangan sabit dari hasil pengukuran dapat dilihat dari beda rerata sesudah mendapatkan pelatihan pada masing-masing kelompok seperti dalam Tabel 4.

Tabel 2. Uji Perbedaan Rerata Kecepatan Tendangan Sabit Sebelum dan Sesudah Pelatihan

\begin{tabular}{ccccccccc}
\hline $\begin{array}{c}\text { Pengukuran } \\
\text { Kecepatan } \\
\text { Tendangan Sabit }\end{array}$ & $\begin{array}{c}\text { Nilai } \\
\text { Minimal }\end{array}$ & $\begin{array}{c}\text { Nilai } \\
\text { Maksimal }\end{array}$ & Rerata & $\begin{array}{c}\text { Simpangan } \\
\text { Baku }\end{array}$ & $\begin{array}{c}\text { Beda } \\
\text { Rerata }\end{array}$ & $\begin{array}{c}\text { Nilai t } \\
\text { hitung }\end{array}$ & $\begin{array}{c}\text { Signifikansi } \\
\text { Hitung }\end{array}$ \\
\hline $\begin{array}{c}\text { Kelompok } \\
\text { Kontrol }\end{array}$ & Tes Awal & 29 & 40 & 33,45 & 3,6976 & & & \\
& Tes Akhir & 35 & 47 & 39,90 & 3,81 & & & 0,00 \\
& & 38 & 33,72 & 3,44 & & & \\
$\begin{array}{c}\text { Kelompok } \\
\text { Perlakuan }\end{array}$ & Tes Awal & 30 & 38,36 & 13,91 & 14,11 & 0,00 \\
& Tes Akhir & 41 & 56 & 47,63 & 47,63 & & & \\
\hline
\end{tabular}


Tabel 3. Persentase Perubahan Kecepatan Tendangan Sabit Setelah Pelatihan

\begin{tabular}{lcc}
\hline \multicolumn{1}{c}{ Hasil Analisis } & Kelompok Perlakuan & Kelompok Kontrol \\
\hline Rerata Tes Awal & 33,72 & 33,45 \\
Rerata Tes Akhir & 47,63 & 39.90 \\
Selisih Rerata & 13,91 & 6,45 \\
Persentase (\%) & 41,25 & 29,28 \\
\hline
\end{tabular}

Tabel 4. Hasil t-independent test Beda Rerata Kecepatan Tendangan Sabit Setelah Perlakuan Pada Kedua Kelompok

\begin{tabular}{lcccc}
\hline Kelompok & $\begin{array}{c}\text { Rerata Tes } \\
\text { Akhir }\end{array}$ & Beda Rerata & Nilai t-hitung & $\begin{array}{c}\text { Nilai Signifikansi } \\
\text { Hitung }\end{array}$ \\
\hline Kontrol & $39,90 \pm 3,806$ & 7,73 & $-3,652$ & 0,001 \\
Perlakuan & $47,63 \pm 5,500$ & & & \\
\hline
\end{tabular}

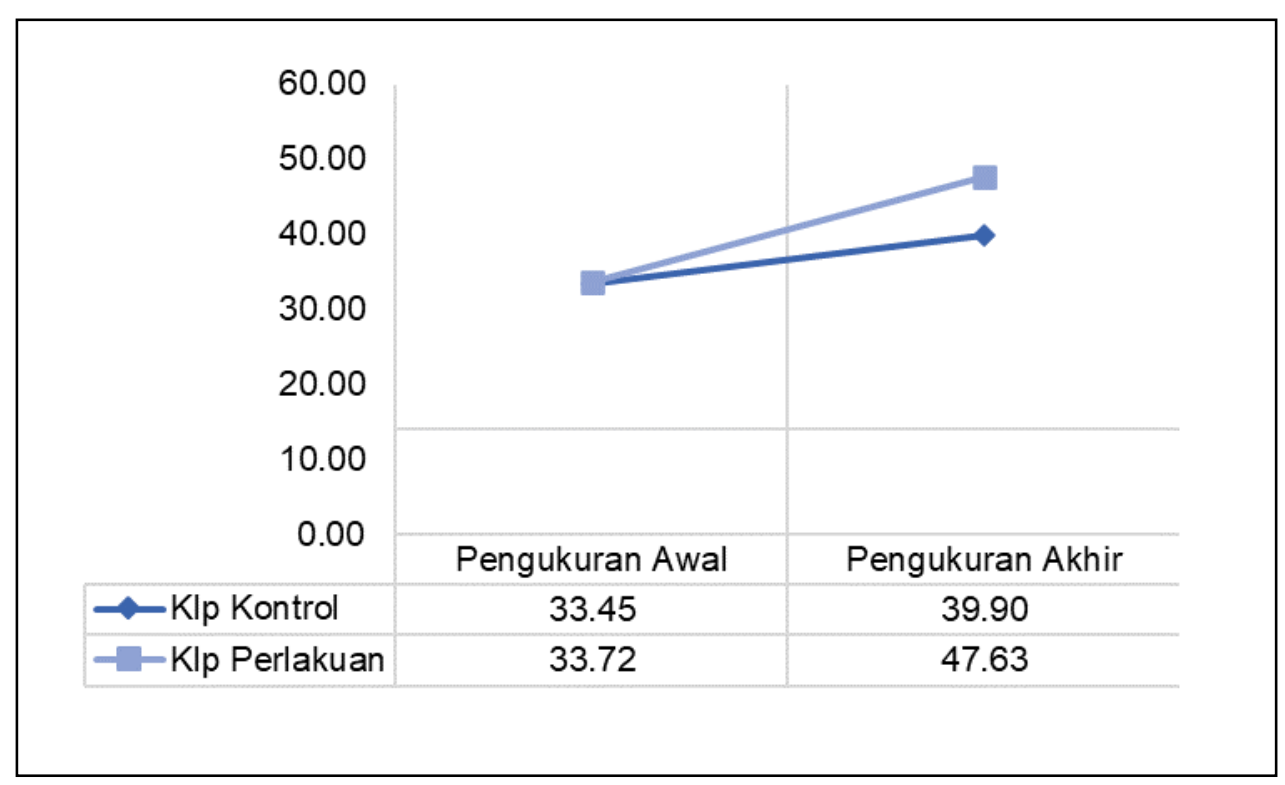

Gambar 1. Rerata Perbedaan Peningkatan Kecepatan Tendangan Sabit

Berdasarkan hasil uji beda rerata dengan menggunakan t-independent test didapatkan hasil nilai $\mathrm{t}$ hitung sebesar $-3,562$ dengan signifikansi hitung sebesar 0,001. Signifikansi hitung dari hasil uji beda rerata kecepatan tendangan sbit antar kelompok lebih kecil dari taraf signifikansi sebesar 0,05. Artinya terdapat perbedaan yang signifikan antara rerata peningkatan kecepatan tendangan sabit kelompok perlakuan dengan kelompok kontrol. Perbedaan peningkatan rerata antar kelompok sebesar 7,73. Kelompok perlakuan yang diberikan pelatihan tendangan drill kanan dan kiri 10 repetisi 5 set menunjukkan peningkatan kecepatan tendangan sabit lebih besar dibandingkan dengan kelompok kontrol.

\section{Pembahasan}

Penelitian ini bertujuan untuk mengetahui pengaruh pelatihan tendangan drill kanan kiri 10 repetisi 5 set terhadap peningkatan kecepatan tendangan sabit atlet putri pencak silat BN Kintara. Hasil analisis yang diperoleh dari penelitian ini terlihat bahwa pelatihan tendangan drill kanan kiri 10 repetisi 5 set memberikan pengaruh yang signifikan terhadap peningkatan kemampuan kecepatan tendangan sabit. Artinya, latihan drill yang diberikan ternyata dapat meningkatkan kecepatan tendangan sabit atlet pencaksilat. Oleh sebab itu, latihan kecepatan tendangan atlet pencak silat harus dilatih secara berkelanjutan dan konsisten sebab kecepatan khususnya kecepatan tendangan harus dimiliki dalam penguasaan suatu teknik dan juga saat bertanding. Penelitian oleh (Nabila, Malinda, Maulana, \& Gilang Panggraita, 2021) menunjukan bahwa latihan merupakan faktor utama dalam meningkatkan kualitas otot dan kekuatan otot merupakan modal untuk mempermudah mempelajari teknik dan mencegah terjadinya cedera dan meperoleh prestasi yang maksimal. Fungsi kecepatan dalam hal ini kecepatan tendangan sabit 
oleh pesilat dapat dilihat pada saat berlaga dalam pertandingan. Jika seorang pesilat menyerang lawan dengan menggunakan tendangan sabit dengan posisi yang monoton maka lawan dengan mudah mengantisipasi tendangan tersebut, baik elakan, tangkapan bahkan serangan. Namun jika tendangan sabit dilakukan dengan cara berpindah tempat dalam waktu secepat-cepatnya kemungkinan lawan akan sulit untuk melakukan antisipasi, sehingga tendangan sabit yang dilakukan dapat tepat pada yang berujung pada perolehan poin. Kecepatan adalah kemampuan tubuh dalam bergerak dalam berpindah tempat dari satu titik ke titik yang lainnya dalam waktu yang sesingkat-singkatnya (Hendri Irawadi, 2014). Hasil penelitian yang dilakukan membuktikan bahwa pelatihan tendangan drill dengan memfokuskan pada kecepatan tendangan sabit dapat mengasah kemampuan atlet baik dari segi teknik maupun kempuan kecepatan tendangannya. Hal ini akan sangat berguna sebagai salah satu penguasaan lapangan saat bertanding. Atlet dapat mengatur serta mengantisipasi serangan dari lawan tanding dengan waktu yang sesingkatsingkatnya setelah melakukan tendangan sabit. Hal ini didukung juga dari hasil penelitian yang dilakukan oleh Sudirjo \& Rukmana (2019) yang menyatakan bahwa tendangan menjadi lebih efektif untuk menghasilkan kemenangan karena memiliki variasi-variasi gerakan jadi pesilat bisa menggunakan jenisjenis tendangan tersebut sesuai dengan strateginya masing-masing.

Penguasaan teknik yang baik dalam olahraga pencak silat merupakan salah satu hal yang harus diperhatikan pesilat dan pelatih. Penting sekali untuk melakukan latihan dengan metode yang benar untuk menghindari cedera, salah satu bentuk pemulihan yang dapat dilakukan dengan cara pemulihan aktif (Lesmana, Padli, \& Broto, 2018). Selain teknik yang baik, kondisi fisik juga merupakan salah satu faktor untuk dapat beprestasi. Dalam pembinaan latihan olahraga pencak silat, pelatih, ataupun para pesilat perlu memperhatikan faktor-faktor kondisi fisik yang mempengaruhi dalam olahraga pencak silat, khususnya untuk mendapatkan kecepatan tendangan yang optimal. Seperti hasil penelitian yang dilakukan oleh (Rosmawati, Darni, \& Syampurma, 2019) terdapat hubungan yang signifikan antara kelincahan dan daya ledak otot tungkai terhadap kecepatan tendangan atlet pencak silat. Selain hal-hal yang telah diuraikan, perlu diperhatikan untuk menjadi pesilat yang berprestasi tentu tidak terbatas pada kecepatan tendangan sabit saja. Faktor lain yang perlu diperhatikan yaitu sikap mental, penguasaan teknik, penguasaan taktik dan juga faktor dukungan keluarga serta motivasi dalam diri untuk menjadi juara. Ilham, Nurul (2015) menyatakan bahwa dalam melakukan kelincahan tendangan sabit diperlukan adannya mental training bagi atlet untuk dapat mencapai penampilan puncak (peak performance). Selai itu, tidak kalah pentingnya, proses recovery setelah latihan atau pertandingan juga menjadi hal yang penting.

\section{SIMPULAN DAN SARAN}

Berdasarkan hasil dan pembahasan dapat disimpulkan bahwa pelatihan tendangan drill kanan kiri 10 repetisi 5 set berpengaruh terhadap peningkatan kecepatan tendangan sabit atlet putri pencak silat BN Kintara. Berdasarkan hasil penelitian ini, diharapkan pelatih dapat menggunakan sebagai referensi tambahan dalam melatih tendangan sabit atlet pencak silat putri. Berdasalkan kesimpulan dapat diimplikasikan bahwa untuk meningkatkan kecepatan tendangan sabit, pesilat putri dapat menggunakan variasi latihan tendangan drill dengan beban latihan 10 repetisi 5 set saat proses latihan. Beban latihan dapat dimodifikasi sesuai dengan kebutuhan dan kemampuan pesilat. Latihan tendangan drill 10 repetisi 5 set memberikan efek yang positif terhadap kemampuan tendangan sabit. Hasil penelitian ini dapat dijadikan dasar pertimbangan untuk meningkatkan kecepatan tendangan sabit pesilat putri. Latihan kecepatan tendangan menggunakan latihan tendangan drill 10 repetisi 5 set telah terbukti dapat meningkatkan kemampuan kecepatan tendangan sabit pencak silat. Model latihan ini dapat dijadikan alternative dalam menentukan variasi latihan pesilat putri. Beberapa hal yang dapat disarankan berdasarkan hasil penelitian ini sebagai berikut. Meningkatkan kecepatan tendangan sabit pencak silat atlet putri, latihan yang dilakukan harus tepat dan berkelanjutan sehingga dapat diperoleh hasil latihan yang optimal. Latihan tendangan drill 10 repetisi 5 set dapat dijadikan salah satu variasi dalam proses latihan untuk dapat meningkatkan kecepatan tendangan sabit pencak silat.

\section{DAFTAR RUJUKAN}

Bangun Novembrian Y.P \& Sugiyoto. (2017). Pengaruh Variasi Latihan Quickness Terhadap Kecepatan Tendangan Sabit Pada Pembinaan Prestasi Pencak Silat Pok Fkip Uns Tahun 2016/2017. Jurnal Olahraga Dan Prestasi, 10(1), 27-33.

Dewi, A. K. (2014). Kontribusi kelincahan dan kecepatan terhadap tendangan sabit pada atlet pencak silat putra usia 12-14 tahun. Jurnal Kesehatan Olahraga, 2(2).

Hamdani. (2014). Evaluasi IMT \& Kondisi Atlet PELATNAS Pencak SilatSEA Games Tahun 2013. PPs Universitas Negeri Surabaya, Surabaya.

Hartoyo, A. R. E. (2015). Survei Pembinaan PenCak Silat Di PerguruAn PencakSilat Se-Kabupaten Wonogiri 
Tahun 2013/2014. Journal of Physical Education, Sport, Health and Recreations, 4(12), 2246-2250. https://doi.org/10.15294/active.v4i12.8797.

Hendri Irawadi. (2014). Kondisi fisik dan pengukurannya. UNP Press: Sukabina.

Ihsan, N., Sepriadi, S., \& Suwirman, S. (2018). Hubungan Status Gizi Dan Motivasi Berprestasi Dengan Tingkat Kondisi Fisik Siswa Pplp Cabang Pencak Silat Sumatera Barat. Sporta Saintika, 3(1), 410 422. https://doi.org/10.24036/sporta.v3i1.61.

Ilham, N. (2015). Hubungan Konsentrasi Terhadap Hasil Belajar Pencak Silat Jurus Tunggal. . 4(1):42 - 44. Jurnal Altius, 4(1), 42-44.

Kholis, M. N. (2016). Aplikasi Nilai-Nilai Luhur Pencak Silat Sarana Membentuk Moralitas Bangsa. Jurnal SPORTI, 2(2), 76-84. $\quad$ Retrieved https://ojs.unpkediri.ac.id/index.php/pjk/article/view/508/390.

Lesmana, H. S. (2019). Profil Delayed Onset Muscle Soreness (Doms) Pada Mahasiswa Fik Unp Setelah Latihan Fisik. Halaman Olahraga Nusantara (Jurnal Ilmu Keolahragaan), 2(1), 50-59.

Lesmana, H. S., \& Broto, E. P. (2018). Profil Glukosa Darah Sebelum, Setelah Latihan Fisik Submaksimal dan Selelah Fase Pemulihan Pada Mahasiswa FIK UNP. Media Ilmu Keolahragaan Indonesia, 8(2), 44-48.

Lesmana, H. S., Padli, P., \& Broto, E. P. (2018). Pengaruh Recovey Aktif dan Pasif Dalam. JOSSAE (Journal of Sport Science and Education), 2(2), 38-41.

Lubis Johansyah \& Wardoyo Hendro. (2016). Pencak Silat Edisi Ketiga. Jakarta: PT RajaGrafindo Persada.

Marlianto, F., Yarman, Sutisyana, A., \& Defliyanto. (2018). Analisis Tendangan Sabit Pada Perguruan Pencak Silat Tapak Suci Di Kota Bengkulu. KINESTETIK : Jurnal Ilmiah Pendidikan Jasmani, 2(2), 179-185. https://doi.org/10.33369/jk.v2i2.8740.

Marlianto, F., \& Yarmani, Y. (2018). Analisis Tendangan Sabit pada Perguruan Pencak Silat Tapak Suci di Kota Bengkulu. Kinestetik: Jurnal Ilmiah Pendidikan Jasmani, 2(2), 179-185.

Muhtar, T. (2020). Pencak silat. UPI Sumedang Press.

Mulyana. (2014). Pendidikan Remaja Silat. Bandung: PT Remaja Rosdakarya.

Nabila, Y., Malinda, M. S., Maulana, Y. I., \& Gilang Panggraita, N. (2021). Pengaruh Latihan Tendangan Menggunakan Ban Karet Terhadap Hasil Tendangan Sabit Pencak Silat. Jurnal HalamanOlahraga Nusantara, 4(1), 77-88. https://doi.org/10.31851/hon.v4i1.5074.

Nala, I. G. N. (2015). Prinsip Pelatihan Fisik Olahraga. In Denpasar: Udayana University Press. Denpasar: Udayana University Press.

Nugraha, B. E. (2014). Analisis Kecepatan Tendangan Pencak Silat Pada Pesilat Unit Kegiatan Mahasiswa Universitas Mulawarman. Samarinda: Universitas Mulawarman.

Nurul Ihsan, S. (2018). Sumbangan Konsentrasi terhadap Kecepatan Tendangan Pencak Silat. Jurnal Media Ilmu Keolahragaan Indonesia, 8(1), 1-6. https://doi.org/10.15294/miki.v8i1.11873.

Palar, C. M., Wongkar, D., \& Ticoalu, S. H. R. (2015). Manfaat latihan olahraga aerobik terhadap kebugaran fisik manusia. EBiomedik, 3(1).

Pratiwi, R. A., Purnomo, E., \& Mimi Haetami. (2018). Pengaruh latihan plyometrik terhadap kecepatan tendangan T Pencak Silat. Jurnal Pendidikan Dan Pembelajaran Khatulistiwa, 8(11).

Rosalina, M. (2017). Profil Atlet Pencak Silat Pra Porda Dilihat Dari Aspek Psikologi Dan Fisiologi. JUARA : Jurnal Olahraga, 2(2), 174-180. https://doi.org/10.33222/juara.v2i2.44.

Rosmawati, F.-U., Darni, F.-U., \& Syampurma, H. (2019). Hubungan Kelincahan Dan Daya Ledak Otot Tungkai Terhadap Kecepatan Tendangan Sabit Atlet Pencak Silat Silaturahmi Kalumbuk Kecamatan Kuranji Kota Padang. Jurnal Menssana, 4(1), 44-52.

Sakti, N. W. P., Wibawa, E., \& Mulyajaya, M. S. (2017). Pengaruh Latihan Ladder Drills Dan Zig Zag Run Terhadap Kelincahan Tendangan Sabit Kanan Kiri Pesilat Putra Tapak Suci Caringin Sukabumi. Prosiding Seminar Nasional Pendidik Dan Pengembang Pendidikan Indonesia Dengan Tema "Membangun Generasi Berkarakter Melalui Pembelajaran Inovatif," 363-370. Retrieved from http://ejournal.mandalanursa.org/index.php/Semnas/article/view/312.

Saputra, J., Syafria, \& Sofino. (2018). Pengaruh Latihan Push -Up Dan Latihan Pull -Up terhadap Kemampuan Pukulan Lurus Olahraga Pencak Silat Pada Siswa Ekstrakurikuler smp Negeri 1kota Bengkulu. KINESTETIK: Jurnal Ilmiah Pendidikan Jasman, 2(1), 104-110. https://doi.org/10.33369/jk.v2i1.9194.

Sinulingga, A., Simatupang, N., \& Mentari, S. P. (2020). Dampak agen sosial terhadap prestasi atlet pusat pendidikan dan latihan pelajar. Jurnal SPORTIF: Jurnal Penelitian Pembelajaran, 6(3), 794-806. https://doi.org/10.29407/js_unpgri. v6i3.15277.

Spyanawati, N. L. P., \& Mudariani, N. W. (2015). Pengaruh Metode Pelatihan Terhadap Keterampilan Jurus Tunggal Pencak Silat Pada Atlet Pemula (10-12 Tahun) di Perguruan Bakti Negara Kecamatan Tegallalang Gianyar. Multilateral: Jurnal Pendidikan Jasmani Dan Olahraga, 14(1), 7-20. 
https://doi.org/10.20527/multilateral.v14i1.2466.

Sudiana, I. K., \& Sepyanawati, N. L. P. (2017). Keterampilan dasar pencak silat. Rajawali Pers.

Sudirjo, E., \& Rukmana, A. (2019). Teknik Serangan Yang Dominan Menghasilkan Kemenangan Pada Pertandingan Pencak Silat Kategori Tanding. SpoRTIVE, 4(1), 401-410.

Sudirman, R. (2015). Pengaruh Metode Latihan Pliometrik Dan Maxex Dengan Kekuatan Terhadap Kecepatan Tendangan Sabit Pencak Silat Di Stkip Setia Budhi Rangkasbitung. Multilateral : Jurnal Pendidikan Jasmani Dan Olahraga, 14(1), 54-61. https://doi.org/10.20527/multilateral.v14i1.2470.

Sukadiyanto dan Dangsina Muluk. (2011). Pengantar teori dan metodologi melatih fisik. Bandung: Lubuk Agung.

Sumantri, R. J., Sulaiman, S., \& Nasuka, N. (2016). Pengaruh media gaya mengajar latihan dan tingkat motor educability terhadap hasil belajar pencak silat. Journal of Physical Education and Sports, $5(2), 127-133$.

Supriyoko, A., \& Mahardika, W. (2018). Kondisi Fisik Atlet Anggar Kota Surakarta. Jurnal SPORTIF : Jurnal Penelitian Pembelajaran, 4(2), 280-292. https://doi.org/10.29407/js_unpgri.v4i2.12540.

Syafruddin. (2011). Ilmu Kepelatihan Olahraga teori dan Aplikasinya Dalam Pembinaan Olahraga. Padang: UNP Press.

Yarmani, \& Japriansyah, Z. (2017). Kontribusi Daya Ledak Otot Tungkai Dan Kelentukan Terhadap Tendangan Belakang Pada Pesilat Padepokan Pencak Silat Bengkulu. Kinestetik: Jurnal Ilmiah Pendidikan Jasmani, 1(2), 75-79. https://doi.org/10.33369/jk.v1i2.10925. 